\title{
THE INFLUENCE OF DIETARY RICE BRAN WITH PHYTASE SUPPLEMENTATION ON GROWTH PERFORMANCE OF GROWING MUSCOVY DUCKS
}

\author{
Adel E. Abou-Zeid ${ }^{1}$, Kh. Amber ${ }^{2}$ and Hala Gamal El-DIN ${ }^{3}$ \\ 1-Animal Production Dep., Faculty of Agriculture, Tanta University, Egypt. \\ 2-Animal Production Dep., Faculty of Agriculture, Kafr El-Sheikh University, Egypt. \\ 3- Environmental and Biological Science Dep. Faculty of Home Economic, Al-Azhar \\ University, Egypt.
}

\section{ABSTRACT}

The purpose of the current study was to assess the effect of rice bran (RB) inclusion with phytase supplementation as a possible feed ingredient in growing Muscovy ducks. One hundred Sixty two 1-dayold males Muscovy ducklings were used to evaluate the effect of using rice bran on growth performance nutrients digestibility, some carcass traits, some plasma constituents and economic efficiency. The effect of RB per se was recognized compared with the control group. The data of final body weight revealed that there were insignificant different among the experimental groups where, ducks fed $0.0 \%$ RB surpassed the other treated groups. Ducks fed $60 \%$ RB had the lowest body weight by $5.7 \%$ followed by birds fed $30 \% \mathrm{RB}$ (2.4\%) compared to the control. The same direction was observed with body weight gain. Statistical differences were noticed with feed conversion ratio between treated groups. The rice bran containing diet $(60 \%)$ increased feed conversion ratio by $14.2 \%$ compared to the control. Final body weight increased significantly with dietary phytase supplementation by (3.4\%) compared to the unsupplemented diet. Growth rate value was increased significantly with phytase supplementation by $4.6 \%$ compared to the unsupplemented diet. Rice bran and phytase supplementation interacted significantly to affect all performance parameters except feed intake. Phytase supplementation increased dry matter $(4.58 \%)$, CP $(4.32 \%)$, EE (2.61\%), NFE (4.16\%), CF (7.14\%), and ME (4.15\%) compared with control. Linear relationship can be noticed between RB and small intestine (\%). The abdominal fat \% decreased by $16.7 \%$ with $60 \%$ followed by $6.6 \%$ with $30 \%$ RB compared with the control. Ducks fed phytase possessed significantly the highest dressing $(1.2 \%)$, GIT $(5.66 \%)$, small intestine $(3.65 \%)$, and pancreas $(4.22 \%)$ compared with the control. Dietary rice bran and phytase interacted significantly to influence all investigated carcass traits except giblets and abdominal fat. Liner relationship was observed between RB inclusion diets and glucose where increasing RB levels from 0 to $60 \%$ leads to decrease glucose level by $17.32 \%$. Glucose, total lipid and cholesterol responded linearly where they decreased with phytase supplement. Glucose decreased by 12.6, total lipid decreased by $7.0 \%$ and cholesterol decreased by $3.5 \%$. Rice bran inclusion interacted significantly with phytase supplementation. Significant differences among treatments groups can be noticed in EE where ducks fed $60 \%$ rice bran was significant higher by $5 \%$ than those fed the control diet while EE in ducks fed 30\% rice bran increased numerically by $4 \%$ than those fed the control. The economic study

Fayoum J. Agric. Res. \& Dev., Vol. 21, No. 2, July, 2007 
showed that lower total feed cost was noticed with $60 \% \mathrm{RB}$ with phytase. It can be concluded that rice bran with microbial phytase could be used up to $60 \%$ in Muscovy ducks diets without any harmful effect on performance and economic efficiency.

Key words: Rice bran, phytase, performance, Muscovy ducks

\section{INTRODUCTION}

The costs of the conventional feedstuffs have been on the increase. This makes it imperative for other less expensive feed materials to be explored. Research into non-conventional feedstuffs mainly aimed at meeting the energy and protein needs of poultry. Therefore, any feed material that holds promise of supplying both protein and energy to a reasonable extent deserve some attention. Rice bran falls into this category. There are 40-45 million Tones of rice bran produced annually in different regions of the world; Far East, South-East Asia and Egypt. The term" rice bran" is used to describe the by product remaining after the milling of brown rice, milling removes the outer layers of rice caryopsis producing white rice which is almost entirely endosperm .The effect of rice bran inclusion into poultry diets is well investigated (Martin and Farrell, 1998, and Lioyd et al., 2000). Rice bran may contain $20-25 \%$ total protein. Rice bran is rich in the vitamin B, amino acid; fat and protein content (Wang et al., 1997). However, rice bran has a high content of fiber (Annison et al., 1995). Rice bran has a major advantage over maize in the wet diets of ducks since rice bran is not normally contaminated with aflatoxin (Sutikno, 1990). Ducks can tolerate the high levels of rice barn in the diets more than broiler chicks without depressing performance (Farrell, 1994). Tangendjaja et al., (1986) showed that Alabio duckling could tolerate up to $75 \%$ rice bran in diet without reduction in growth rate or poor feed conversion ratio. Since humans consume little rice bran, there is an enormous wastage of important nutrients in the 40-45 million Tones of rice bran produced annually. A major problem with rice bran that makes it limited to use in poultry diets is therefore its variation in chemical composition that may be associated with depressed performance of poultry (Zeweil $\boldsymbol{e t}$ al., 2005). Hull adulteration appears to be the most important constraint to the utilization of rice bran particularly when the hull content is greatest than $100 \mathrm{~g} / \mathrm{kg}$ of rice bran. Others major disadvantages with rice bran are phytic acid and high oil content. High oil content under some circumstances may produce extreme hydrolytic and oxidative rancidity and poor livestock acceptability. The anti-nutritive effects of phytic acid and its effect on nutrient utilization have been given a vast coverage in the literature, but with correspondingly obscure and conflicting information on its influence on nutrient retention and growth. However, the reported inability of monogastric animals to utilize phytate bound $\mathrm{P}$ entails incorporation of inorganic $\mathrm{P}$ in poultry diets, which aggravates the increase in phosphorus excretion (as environmental pollutant) as well as increasing the cost of feed. To solve this problem and to diminish the detrimental effect of using rice bran at large scale in poultry diets, the thought of using microbial phytase has become urgent. Positive effects associated with microbial phytase supplementation in poultry diets include improved performance have been shown in the study of Ravindran et al. (2001), Onyango et al., (2005) and Olukosi et al., (2007). The benefits gained from microbial phytase addition to the poultry diets appear to be mediated through the reduction of endogenous losses of amino

Fayoum J. Agric. Res. \& Dev., Vol. 21, No. 2, July, 2007 
acid, calcium, sodium and phosphorus (Cowieson et al., 2004). Ravindran et al. (2001) showed in their investigation that the addition of phytase to a lysine deficient diet significantly improved not only the ileal digestibility of lysine but also other amino acid, therefore, resulting in improved broiler performance. The improvement in broiler performance could be attributed to the effect of phytase supplementation on the absorptive capacity of the digestive tract. Wu et al. (2004) noticed some increases in villi height in the duodenum indicating that phytase stimulates the absorptive capacity of the digestive canal.

The present experiment aimed to study the effect of rice bran inclusion to duck diets with microbial phytase supplementation to improve duck performance with the best economic efficiency.

MATERIAL and METHODS

Experimental procedure: One hundred and sixty two - 1- day old males Muscovy ducklings were wing banded, individually weighed and distributed randomly to six equal experimental groups of 27 birds each. Ducks of each group were further subdivided into three replicates of 7 ducks each and housed in floor pens. Accessible running fresh water was provided. Standard management techniques and environmental conditions were applied. Classical performance traits were recorded weekly.

Diets: A conventional starter and grower duck mash diets were formulated to meet or exceed the minimum national research council recommendation (NRC, 1994). The commercial starter diet was offered to the ducklings for the first 5 weeks of age. At 5 weeks of age, the rice bran was introduced to the basal growing diet at the levels of 0,30 and $60 \%$ to formulate the tested experimental diets. The experimental period lasted for 6 weeks (5-11 weeks). Each diet was tested with or without microbial phytase at the level of 800 FTU/kg. The composition and chemical analysis of the experimental diet is detailed in Table (1).

Digestibility trial: A digestibility trial was performed to determine the digestibility coefficients of nutrient. For each treatment, 4 male ducks were housed in individual metabolic cages. The ducks were fed the tested diets, feed intake and feces output were recorded daily over five consecutive days. The samples of daily feces of each duck were sprayed with $1 \%$ boric acid solution to prevent ammonia losses during drying. Samples of the dried feed and feces were prepared for chemical analysis.

Chemical Analyses: Chemical analyses were performed for diets, feces and meat (mixture of breast and thigh) samples, according to the methods of A.O.A.C (1995).

Slaughter test: At the end of the experiment, 3 male ducks from each treatment were chosen and slaughtered after fasting for 10 hours for carcass evaluation. Classical carcass traits were measured according to guidelines of Blasco et al. (1992).

Plasma biochemical analysis: Plasma was obtained after slaughter immediately by centrifugation of heparinzed blood for $10 \mathrm{~min}$. at $3000 \mathrm{rpm}$ and frozen rapidly in ependorf tubes at $-20^{\circ} \mathrm{C}$ until time of analysis. Plasma total protein and albumin were measured according to Armstrong and Carr (1964). Total lipids, cholesterol and glucose were measured by specific diagnostic kits (Bio Mereux, France) according to the guidelines and recommendation of Bogin and Keller (1987).

Fayoum J. Agric. Res. \& Dev., Vol. 21, No. 2, July, 2007 
Adel E. Abou-Zeid, et al.,

Table (1) : Formulation and chemical analysis of experimental diets.

\begin{tabular}{|c|c|c|c|}
\hline \multirow{2}{*}{ Ingredients } & \multicolumn{3}{|c|}{ Rice bran level (\%) } \\
\hline & 0 & 30 & 60 \\
\hline Yellow corn & 60 & 30 & --- \\
\hline Rice bran (RB) & --- & 30 & 60 \\
\hline Wheat bran & 18.2 & 20.5 & 22.3 \\
\hline Soybean meal (44\%) & 10.7 & 7.6 & 3.8 \\
\hline Broiler concentrate $(52 \%)^{*}$ & 10 & 10 & 10 \\
\hline Sunflower oil & --- & 0.9 & 2.9 \\
\hline Limestone & 0.5 & 0.5 & 0.5 \\
\hline DL-methionine & 0.1 & --- & --- \\
\hline Salt & 0.2 & 0.2 & 0.2 \\
\hline Premix ** & 0,3 & 0.3 & 0.3 \\
\hline Total & 100 & 100 & 100 \\
\hline \multicolumn{4}{|l|}{ Calculated analysis } \\
\hline Metabolizable energy (ME) Kcal/kg diet & 2998 & 2918 & 2902 \\
\hline Crude protein $(\mathrm{CP})$ & 17.37 & 17.52 & 17.64 \\
\hline Ether extract (EE) & 3.22 & 6.91 & 11.76 \\
\hline Crude fiber $(\mathrm{CF})$ & 4.62 & 6.89 & 9.34 \\
\hline Lysine & 0.86 & 0.88 & 0.91 \\
\hline Methonine & 0.49 & 0.50 & 0.61 \\
\hline Calcium & 1.01 & 1.02 & 1.05 \\
\hline Total phosphorus & 0.71 & 1.12 & 1.56 \\
\hline
\end{tabular}

*Broiler concentrate: ME (Kcal /Kg) 2725, CP 52\%, Methionine 1.7, Lysine $2.9 \%$, Methionine \& Cystine $2.0 \%$, Calcium $7.4 \%$, Phosphorus $2.9 \%$, CF 2.3\%, EE $4 \%$.

**Each 3 kg premix contain: vit. A 12000000 IU, vit. D3 2000000 IU, vit. E 10000 mg, vit. K $2000 \mathrm{mg}$, vit. $B_{1} 1000 \mathrm{mg}$, vit. $B_{2} 5000 \mathrm{mg}$, vit. $B_{6} 1500 \mathrm{mg}$, vit. $B_{12} 10 \mathrm{mg}$, Folic acid $1000 \mathrm{mg}$, Biotin $50 \mathrm{mg}$, Pantothenic acid $10000 \mathrm{mg}$, Niacin $30000 \mathrm{mg}$, Fe 30000 $\mathrm{mg}, \mathrm{Cu} 10000 \mathrm{mg}$ and Se $100 \mathrm{mg}$, Zinc $50000 \mathrm{mg}$, manganese $60000 \mathrm{mg}$.

Statistical analysis: All data were subjected to statistical analysis in a factorial design as reported measures using invariant analysis of variance with the GLM SAS procedure (Der and Everitt, 2001). All percentage records were transformed to arcsin before analysis. Significant differences among means were tested by the method of Duncan (1955).

Economical efficiency: At the end of experimental period, the economical efficiency of growing ducks under the circumstance of the study was estimated by input- output analysis. The Economical efficiency \% was calculated using the selling price of weight gain and the feeding cost of this gain prevailing in the market, assuming that other costs were constant. The data were evaluated according to the price available in Egyptian market at marketing time.

Economical efficiency $\%=[(\mathrm{A}-\mathrm{B}) / \mathrm{B}] \times 100$ where:

$\mathrm{A}=$ selling cost of obtained gain, $\mathrm{B}=$ feeding cost of this gain.

Fayoum J. Agric. Res. \& Dev., Vol. 21, No. 2, July, 2007 
THE INFLUENCE OF DIETARY RICE BRAN WITH PHYTASE ....

\section{RESULTS}

\section{Effects of rice bran on performance traits:-}

Performance data of Muscovy ducks as influenced by RB levels with or without dietary phytase are illustrated in Table (2). Initial body weights did not statistically differ among experimental groups. The effect of RB per se was recognized compared with the control group. The data of final body weight revealed that there were significant differences among the experimental groups where, ducks fed $0.0 \% \mathrm{RB}$ surpassed the other treated groups. Ducks fed $60 \% \mathrm{RB}$ had the lowest body weight by $5.7 \%$ followed by birds fed $30 \%$ $\mathrm{RB}(2.4 \%)$ compared to the control. These results showed that there is a linear relationship between RB levels and final body weight, as the level of RB increased a significant decrease in body weight occurred.

The same direction was observed with daily body weight gain, where ducks fed the control diet had the highest weight gain value compared to the other treatments groups. Body weight gain of birds received 30 and $60 \% \mathrm{RB}$ had significantly lower weight gain by (5.5 and $11.9 \%)$, respectively as compared with the control.

From the results located in Table (2), it is obvious that growth rate values were significantly influenced by different levels of $\mathrm{RB}$. The growth rate value decreased significantly with increasing $\mathrm{RB}$, where increasing RB levels from $(0.0 \%)$ to $(30$ and $60 \%)$ resulted in decreasing growth rate value by (4.2) and $(8.7) \%$, respectively. The effects of different dietary RB levels on Feed intake are illustrated in Table (2). Feed intake was not statistically affected by rice bran inclusion in diets. Statistical differences were noticed with feed conversion ratio between treated groups. The rice bran containing diet $(60 \%)$ had lower feed conversion ratio by $14.2 \%$ compared to the control while birds received $30 \%$ rice bran had lower feed conversion ratio by $7.1 \%$ as compared with ducks fed control diet.

Effect of phytase on performance traits:

Data in Table (2) clearly showed that initial body weight values were not statistically different among treatment groups. Final body weight increased significantly with dietary phytase supplementation by (3.4) \% compared to the un-supplemented diet. The birds fed 800 FTU/ Kg recorded the highest body weight gain value by (7.0)\% compared to the birds fed diet without phytase. Growth rate value increased significantly with phytase supplementation by (4.6)\% compared to the un-supplemented diet .It is obvious from Table (2) that feed intake decreased significantly with birds fed 800 (FTU/Kg phytase) by (4.3)\% compared with un-supplemented diet. Feed conversion ratio of group fed phytase showed the best value by (10.6) \% compared with those fed the un-supplemented diet.

\section{Interaction: -}

Rice bran and phytase supplementation interacted significantly to affect all performance parameters except feed intake. The highest final body weight was noticed with ducks fed diet without rice bran but supplemented with phytase, while the lowest record was noticed with ducks fed $60 \%$ rice bran without phytase supplementation. The same trend was also noticed with body weight gain and growth rate. The data of feed conversion ratio showed that the ducks fed $(0.0 \%) \mathrm{RB}$ with phytase possessed the best feed conversion ratio while the worst value was noticed in ducks fed the $60 \% \mathrm{RB}$ without phytase.

Fayoum J. Agric. Res. \& Dev., Vol. 21, No. 2, July, 2007 
It is important to note that mortality rate in Muscovy ducks was 0.0 with ducks fed different dietary RB while it was 2 ducks fed control diet without phytase and one duck from ducks fed control diet with phytase (7.41 and $3.70 \%$ ), respectively, and the diarrhea was the cause during the whole experimental period. This could be attributed to anti-mucotoxin effect of RB and not contaminated with aflatoxin (Sutikno, 1990).

Table 2: The effect of the experimental diets on performance of growing Muscovy ducks

\begin{tabular}{|c|c|c|c|c|c|c|}
\hline Treatments & $\begin{array}{l}\text { Initial } \\
\text { body } \\
\text { weight } \\
\text { (g) }\end{array}$ & $\begin{array}{l}\text { Final } \\
\text { body } \\
\text { weight } \\
\text { (g) }\end{array}$ & $\begin{array}{c}\text { Daily } \\
\text { body } \\
\text { weight } \\
\text { gain } \\
\text { (g/d) }\end{array}$ & $\begin{array}{c}\text { Growth } \\
\text { rate } \\
(\%)\end{array}$ & $\begin{array}{c}\text { Feed } \\
\text { intake } \\
(\mathrm{g} / \mathrm{d})\end{array}$ & $\begin{array}{c}\text { Feed } \\
\text { conversion } \\
\text { ratio } \\
(\mathrm{g} / \mathrm{g})\end{array}$ \\
\hline Rice bran (RB\%) & & & & & & \\
\hline 0 & 1972 & $3949^{\mathrm{a}}$ & $47.1^{\mathrm{a}}$ & $66.8^{\mathrm{a}}$ & 200 & $4.2^{\mathrm{c}}$ \\
\hline 30 & 1987 & $3856^{\mathrm{b}}$ & $44.5^{\mathrm{b}}$ & $64.0^{\mathrm{b}}$ & 202 & $4.5^{\mathrm{b}}$ \\
\hline 60 & 1983 & $3724^{\mathrm{c}}$ & $41.5^{\mathrm{c}}$ & $61.0^{\mathrm{c}}$ & 200 & $4.8^{\mathrm{a}}$ \\
\hline SE & 34.7 & 65.9 & 1.47 & 1.76 & 2.75 & 0.09 \\
\hline \multicolumn{7}{|l|}{ Phytase (800FTU/kg) } \\
\hline- & 1980 & $3779^{b}$ & $42.8^{\mathrm{b}}$ & $62.5^{\mathrm{b}}$ & 205 & $4.7^{\mathrm{a}}$ \\
\hline+ & 1981 & $3906^{\mathrm{a}}$ & $45.8^{\mathrm{a}}$ & $65.4 \mathrm{a}$ & 196 & $4.2^{\mathrm{b}}$ \\
\hline SE & 26.4 & 49.1 & 1.21 & 1.42 & 2.15 & 0.07 \\
\hline \multicolumn{7}{|l|}{ Interaction: } \\
\hline \multirow[t]{2}{*}{$\mathbf{0}$} & 1978 & $3907^{\mathrm{b}}$ & $45.9^{\mathrm{b}}$ & $65.61^{b}$ & 205 & $4.4^{\mathrm{b}}$ \\
\hline & 1965 & $3990^{\mathrm{a}}$ & $48.2^{\mathrm{a}}$ & $68.0^{\mathrm{a}}$ & 195 & $4.0^{\mathrm{c}}$ \\
\hline \multirow[t]{2}{*}{30} & 1982 & $3801^{\mathrm{c}}$ & $43.3^{\mathrm{c}}$ & $62.9^{c}$ & 200 & $4.6^{\mathrm{b}}$ \\
\hline & 1991 & $3911^{b}$ & $45.7^{\mathrm{b}}$ & $65.1^{\mathrm{b}}$ & 205 & $4.4^{\mathrm{b}}$ \\
\hline 60 & 1979 & $3630^{\mathrm{d}}$ & $39.3^{\mathrm{e}}$ & $58.9^{\mathrm{e}}$ & 210 & $5.3^{\mathrm{a}}$ \\
\hline$\frac{+}{\mathrm{CF}}$ & 1986 & $3818^{\mathrm{c}}$ & $43.6^{\mathrm{c}}$ & $63.1^{\mathrm{c}}$ & 190 & $4.3^{b}$ \\
\hline SE & 46.2 & 126 & 1.96 & 2.35 & 3.63 & 0.12 \\
\hline \multicolumn{7}{|l|}{ Significance } \\
\hline Rice bran & NS & $* * *$ & $* * *$ & $* * *$ & NS & $*$ \\
\hline Phytase & NS & $* * *$ & $* * *$ & $* * *$ & $*$ & $*$ \\
\hline Rice bran $\times$ Phytase & NS & $*$ & $*$ & $*$ & NS & $*$ \\
\hline
\end{tabular}

a,b,c,e Means within column for each item having different superscript differ significantly $*(\mathrm{P} \leq 0.05)$

$\mathrm{NS}=$ Not significant

$* * *(\mathrm{P} \leq 0.001)$

Effect of rice bran on apparent digestibility coefficient of nutrients:-

The results in Table (3) showed that rice bran inclusion to the ducks diets induced significant effects on apparent digestibility of nutrients in all investigated parameters. The results of the digestibility coefficients of DM, $\mathrm{CP}, \mathrm{EE}, \mathrm{NFE}, \mathrm{CF}$, and ME indicated that the ducks fed $60 \% \mathrm{RB}$ had the lowest values of digestibility coefficients except EE and ME. The DM decreased by $14.6 \%, \mathrm{CP}$ by $11.8 \%$, NFE by $9.5 \%$, CF by $14.02 \%$, compared with the control. 
Effect of phytase supplementation on apparent digestibility coefficient of nutrients: -

It can be noticed from Table (3) that phytase supplementation increased digestion of DM (4.58\%), CP (4.32\%), EE (2.61\%), NFE(4.16\%), $\mathrm{CF}(7.14 \%)$, and $\mathrm{ME}(4.15 \%)$ compared with control.

\section{Interaction}

Rice bran and phytase supplementation interacted significantly to affect apparent digestibility coefficients of nutrients. The highest DM digestibility coefficient was recorded with birds fed (0 RB + phytase) while the lowest value was noticed with birds fed (60\% RB without phytase) .The same observation was noticed with $\mathrm{CP}, \mathrm{NEF}$, and $\mathrm{CF}$

Table (3): The effect of the experimental diets on apparent digestibility (\%) and metabolisable energy (Kcal/kg) of growing Muscovy ducks.

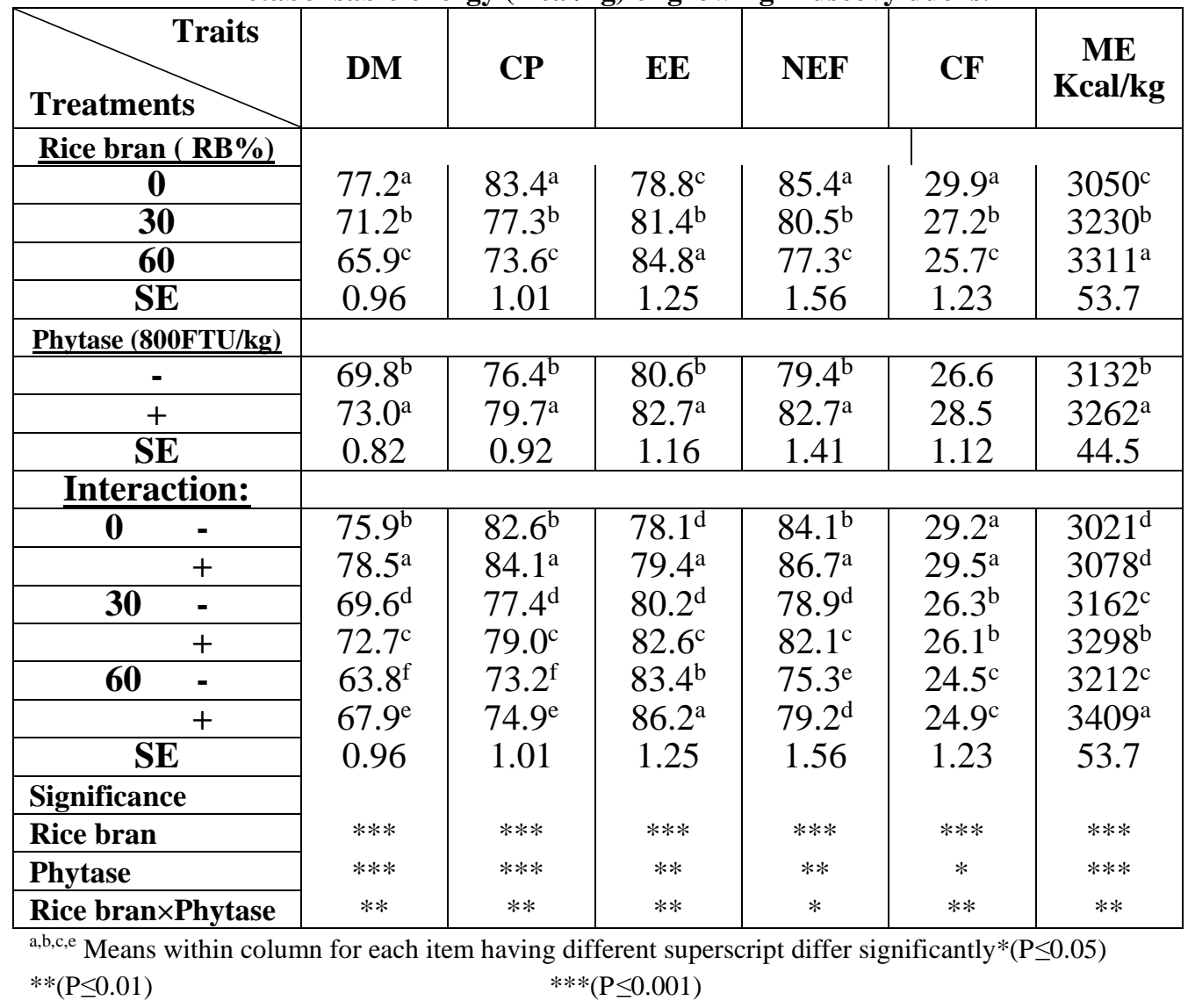

Effect of rice bran inclusion on carcass traits:

Results of slaughter test of birds fed RB (\%) and microbial phytase levels are summarized in Table 4. Statistical analysis revealed significant differences in all carcass traits \% "dressing, giblets, GIT, abdominal fat, small intestine and pancreas". It can be noticed that dressing (\%) decreased significantly. with increasing RB from 0 to 30 and 60 by (2.3 and 6.3), respectively, at the same time, Giblets $(\%)$ increased dramatically by $(0.34$ and $2.1)$, respectively. 
Adel E. Abou-Zeid, et al.,

Another trend can be noticed with GIT (\%) where birds fed $60 \%$ RB possessed higher GIT (\%) by $28.1 \%$ followed by birds fed $30 \%$ RB (12.5\%) compared to the control group. Linear relationship can be noticed between RB and small intestine, where increasing $\mathrm{RB}$ level resulted in increasing small intestine. The birds fed $60 \% \mathrm{RB}$ had statistically higher small intestine by $23.7 \%$ followed by birds fed $30 \% \mathrm{RB}$ (14.1) compared to the control group. The abdominal fat $\%$ decreased by $16.7 \%$ with $60 \%$ followed by $6.6 \%$ with $30 \%$ RB compared with the control. The same trend was also detected with pancreas (\%) where birds fed $60 \%$ RB had statistically the highest pancreas $\%$ by 13.6 compared to the control group.

Effect of phytase levels on carcass traits:-

Results of carcass traits of birds fed diets supplemented with phytase are summarized in Table 4. Statistical analysis revealed significant differences in all investigated parameters except giblets $\%$. Ducks fed phytase possessed significantly the highest dressing (1.2\%), GIT (5.66\%), small intestine (3.65\%), and pancreas $(4.22 \%)$ compared with the control.

Table 4: The effect of the experimental diets on carcass traits of growing Muscovy ducks.

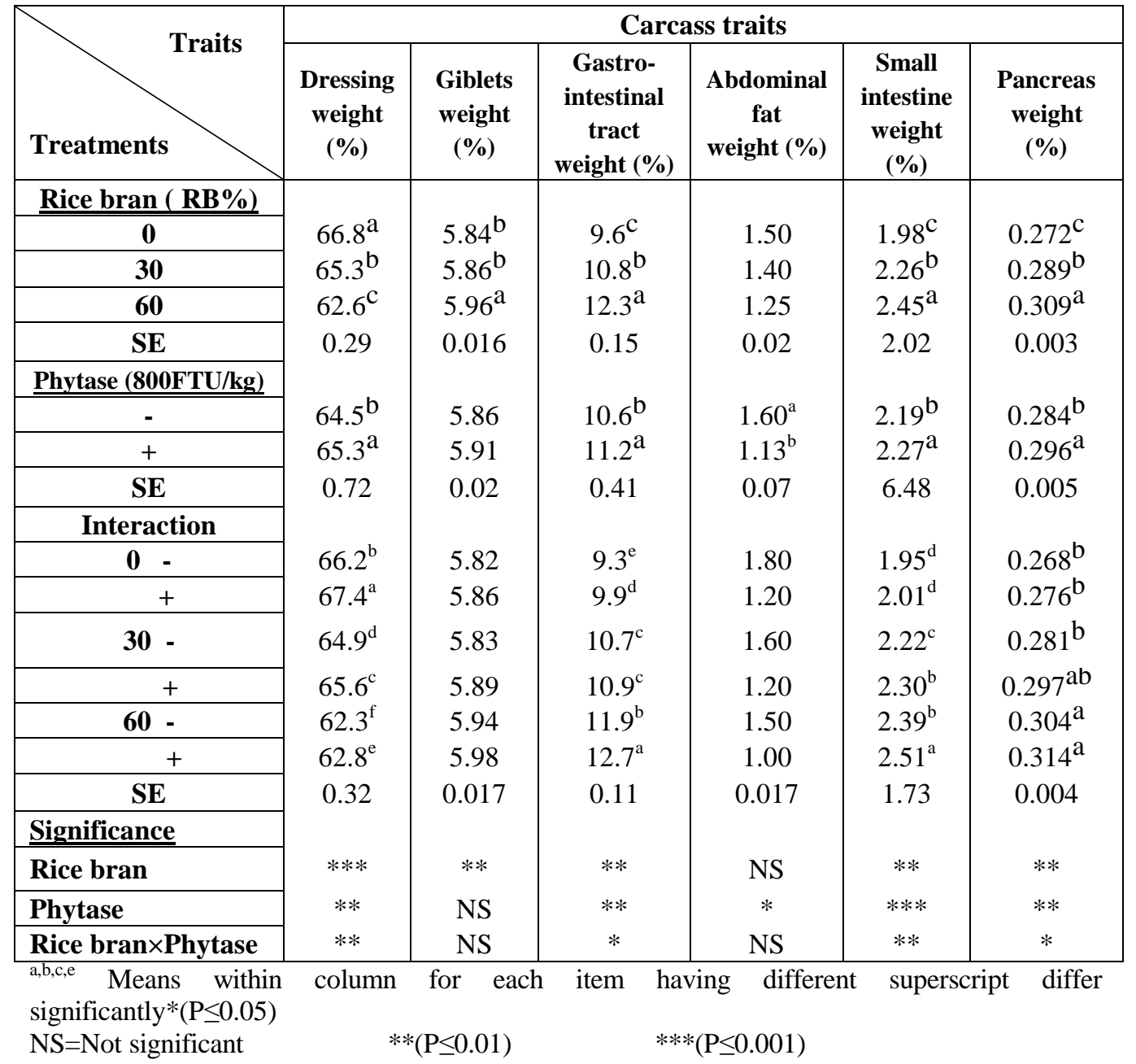

Fayoum J. Agric. Res. \& Dev., Vol. 21, No. 2, July, 2007 


\section{Interaction}

Dietary rice bran and phytase interacted significantly to influence all investigated carcass traits except giblets and abdominal fat. The higher records of giblets, GIT and small intestine were observed with ducks fed (60\% RB + phytase), while the lowest record was noticed with ducks fed $(0.0 \% \mathrm{RB}$ without phytase). Dressing \% showed another trend where the highest value was in ducks fed $(0.0+$ phytase $)$, while the lowest record noticed in ducks fed $60 \%$ RB without phytase.

\section{Effect of rice bran inclusion on plasma constituents:-}

The results of plasma biochemical analyses are tabulated in Table 5. It can be noticed that there were statistical differences among experimental groups. A Linear relationship was observed between RB inclusion in diets and plasma glucose where increasing RB levels from 0 to $60 \%$ leads to decrease glucose level by $17.32 \%$. The same trend was noticed with total protein by (23.9), Total lipids (4.4) and cholesterol (10.6).

Effect of phytase supplementation on plasma constituents: -

From Table 5, it can be noticed that ducks responded to phytase supplementation. Glucose, total lipid and cholesterol responded linearly where they decreased with phytase supplement. Glucose decreased by 12.6 , total lipid decreased by $7.0 \%$ and cholesterol decreased by $3.5 \%$.

Table (5): The effect of the experimental diets on plasma constituent of growing Muscovy ducks.

\begin{tabular}{|c|c|c|c|c|}
\hline$\overbrace{\text { Treatments }}^{\text {Traits }}$ & $\begin{array}{l}\text { Glucose } \\
(\mathrm{mg} / \mathrm{dl})\end{array}$ & $\begin{array}{l}\text { Total } \\
\text { Protein } \\
\text { (mg/dl) }\end{array}$ & $\begin{array}{l}\text { Lipids } \\
\text { (mg/dl) }\end{array}$ & $\begin{array}{c}\text { Cholesterol } \\
\text { (mg/dl) }\end{array}$ \\
\hline Rice bran ( RB\%) & & & & \\
\hline 0 & $179^{\mathrm{a}}$ & $6.16^{\mathrm{a}}$ & $7.80^{\mathrm{a}}$ & $207^{\mathrm{a}}$ \\
\hline 30 & $162^{b}$ & $5.34^{\mathrm{b}}$ & $7.55^{\mathrm{b}}$ & $193^{\mathrm{b}}$ \\
\hline 60 & $148^{\mathrm{c}}$ & $4.69^{c}$ & $7.05^{\mathrm{c}}$ & $185^{\mathrm{c}}$ \\
\hline SE & 2.74 & 0.059 & 0.075 & 2.21 \\
\hline Phytase (800FTU/kg) & & & & \\
\hline- & $167^{\mathrm{a}}$ & $5.17^{\mathrm{b}}$ & $7.74^{\mathrm{a}}$ & $198^{\mathrm{a}}$ \\
\hline+ & $146^{\mathrm{b}}$ & $5.62^{\mathrm{a}}$ & $7.20^{\mathrm{b}}$ & $191^{b}$ \\
\hline$S E$ & 4.35 & 021 & 0.015 & 2.02 \\
\hline$\frac{\text { Interaction: }}{\text { Rice bran } \times \text { Phytase }}$ & & & & \\
\hline 0 & $182^{\mathrm{a}}$ & $6.00^{\mathrm{b}}$ & $8.11^{\mathrm{a}}$ & $209^{\mathrm{a}}$ \\
\hline+ & $176^{\mathrm{b}}$ & $6.33^{\mathrm{a}}$ & $7.49^{\mathrm{c}}$ & $204^{b}$ \\
\hline 30 & $166^{\mathrm{c}}$ & $5.00^{\mathrm{d}}$ & $7.81^{\mathrm{b}}$ & $195^{\mathrm{c}}$ \\
\hline+ & $158^{\mathrm{d}}$ & $5.68^{\mathrm{c}}$ & $7.30^{\mathrm{d}}$ & $190^{\mathrm{d}}$ \\
\hline 60 & $154^{\mathrm{d}}$ & $4.53^{\mathrm{t}}$ & $7.30^{\mathrm{d}}$ & $189^{\mathrm{d}}$ \\
\hline+ & $142^{\mathrm{e}}$ & $4.85^{\mathrm{e}}$ & $6.80^{\mathrm{e}}$ & $180^{\mathrm{e}}$ \\
\hline$S E$ & 3.46 & 0.041 & 0.046 & 2.31 \\
\hline Significance & & & & \\
\hline Rice bran & $* * *$ & $* * *$ & $* *$ & $* * *$ \\
\hline Phytase & $* *$ & $*$ & $*$ & * \\
\hline Rice bran $\times$ Phytase & $*$ & $*$ & $*$ & $*$ \\
\hline
\end{tabular}

${ }^{\text {a,b,c,e }}$ Means within column for each item having different superscript differ significantly $(\mathrm{P} \leq 0.05)$ $* *(\mathrm{P} \leq 0.01) \quad * * *(\mathrm{P} \leq 0.001)$

Fayoum J. Agric. Res. \& Dev., Vol. 21, No. 2, July, 2007 


\section{Interaction:}

Rice bran inclusion interacted significantly with phytase supplementation. The highest glucose concentration was observed with (control diet without phytase supplementation) while the lowest value was noticed with $(60 \% \mathrm{RB}$ with phytase supplementation). The same trend was also noticed with total lipid and cholesterol. The higher total protein value was noticed from birds fed ( 0 rice bran + phytase) while the lowest one noticed with the birds fed $(60 \% \mathrm{RB}$ without phytase).

\section{Effect of RB on chemical composition of meat: -}

Significant differences among treatments groups can be noticed in EE where ducks fed $60 \%$ rice bran was significant higher by $5 \%$ than those fed the control diet while EE in ducks fed $30 \%$ rice bran increased numerically by $4 \%$ than those fed the control (Table 6). Rice bran levels did not affect the $\mathrm{DM}, \mathrm{CP}$ and ash significantly.

\section{Effect of phytase: -}

It is obvious from Table 6 that phytase supplementation did not induce any significant effects on DM, CP, EE and ash.

\section{Interaction}

The interaction data clearly showed that there were no significant differences in DM, CP, EE, and ash by using phytase with different rice bran levels.

Table (6): Chemical composition of Muscovy duck meat as affected by feeding the experimental diets

\begin{tabular}{|c|c|c|c|c|}
\hline \multirow{2}{*}{ Treatments } & \multicolumn{4}{|c|}{ Chemical composition of Muscovy meat } \\
\hline & $\begin{array}{c}\text { Dry } \\
\text { Matter } \\
\text { DM }\end{array}$ & $\begin{array}{c}\text { Crude } \\
\text { Protein } \\
\text { CP }\end{array}$ & $\begin{array}{c}\text { Ether } \\
\text { Extract } \\
\text { EE }\end{array}$ & Ash \\
\hline Rice bran (RB\%) & & & & \\
\hline 0 & 71.7 & 24.9 & $19.9^{\mathrm{D}}$ & 8.4 \\
\hline 30 & 71.2 & 24.8 & $20.7^{\mathrm{ab}}$ & 8.1 \\
\hline 60 & 70.9 & 25.2 & $20.9^{\mathrm{a}}$ & 8.3 \\
\hline SE & 0.37 & 0.36 & 0.23 & 0.25 \\
\hline \multicolumn{5}{|l|}{ Phytase (800FTU/kg) } \\
\hline- & 71.1 & 24.7 & 20.4 & 8.2 \\
\hline+ & 71.4 & 25.2 & 20.6 & 8.3 \\
\hline$S E$ & 0.26 & 0.27 & 0.23 & 0.22 \\
\hline \multicolumn{5}{|l|}{$\frac{\text { Interaction }}{\text { Rice bran } \times \text { Phytase }}$} \\
\hline $\begin{array}{ll}\mathbf{0} & - \\
\end{array}$ & 71.5 & 24.7 & 19.8 & 8.5 \\
\hline \multirow[b]{2}{*}{30} & 71.9 & 25.1 & 20.0 & 8.3 \\
\hline & 71.1 & 24.4 & 20.6 & 7.9 \\
\hline+ & 71.3 & 25.2 & 20.8 & 8.3 \\
\hline \multirow{2}{*}{$\begin{array}{ll}60 & - \\
& +\end{array}$} & 70.7 & 25.1 & 20.7 & 8.2 \\
\hline & 71.1 & 25.3 & 21.1 & 8.4 \\
\hline$S E$ & 0.46 & 0.41 & 0.35 & 0.40 \\
\hline Significance & & & & \\
\hline Rice bran & NS & NS & $*$ & NS \\
\hline Phytase & NS & NS & NS & NS \\
\hline Rice bran $\times$ Phytase & NS & NS & NS & NS \\
\hline
\end{tabular}

Fayoum J. Agric. Res. \& Dev., Vol. 21, No. 2, July, 2007 
Economic efficiency:

Data of growth performance were subjected to economic study (Table 7). Mortality was taken into consideration to calculate the total meat yield. The results showed that lower total feed cost was noticed with $60 \%$ RB with phytase. This reduction may be due to the lower feed intake and price. However, total meat yield was higher in the control diet with phytase due to higher weight gain. The highest values of relative revenue (\%) were observed in ducks fed 30 or $60 \% \mathrm{RB}$ diets with phytase (120.5 and $120.7 \%$, respectively) while lowest value was found in those fed $60 \%$ RB diet without phytase (101.3\%). It can be concluded that rice bran with microbial phytase could be used up to $60 \%$ in Muscovy duck diets without any harmful effect on performance and economic efficiency.

Table (7): Economical efficiency of Muscovy ducks fed different levels of RB without (-) or with(+) microbial phytase.

\begin{tabular}{|l|c|c|c|c|c|c|}
\hline \multirow{2}{*}{ Items } & \multicolumn{7}{c|}{ Level of RB(\%) } \\
\cline { 2 - 8 } & \multicolumn{2}{|c|}{0} & \multicolumn{2}{c|}{30} & \multicolumn{2}{c|}{60} \\
\cline { 2 - 8 } & - & + & - & + & - & + \\
\hline No. of survival ducks & 25 & 26 & 27 & 27 & 27 & 27 \\
\hline Feed intake(Kg/duck) & 8.61 & 8.19 & 8.40 & 8.61 & 8.82 & 7.98 \\
\hline Total feed intake(kg) & 215.3 & 212.9 & 226.8 & 232.5 & 238.1 & 215.5 \\
\hline Price/kg diet(L.E) & 0.86 & 0.88 & 0.66 & 0.69 & 0.61 & 0.63 \\
\hline Total feed cost(L.E) & 185.2 & 187.4 & 149.7 & 160.4 & 145.2 & 135.8 \\
\hline Weight gain (kg/bird) & 1.928 & 2.024 & 1.819 & 1.919 & 1.651 & 1.831 \\
\hline Total meat yield(kg) & 48.2 & 52.6 & 49.1 & 51.8 & 44.6 & 49.4 \\
\hline Selling price* (L.E) & 482 & 526 & 491 & 518 & 446 & 494 \\
\hline Net revenue** (L.E) & 296.8 & 338.6 & 341.3 & 357.6 & 300.8 & 358.2 \\
\hline Relative revenue & 100 & 114.1 & 115.0 & 120.5 & 101.3 & 120.7 \\
\hline Rice bran=550 LE & \multicolumn{2}{|c|}{ kg meat=10 LE } & & &
\end{tabular}

\section{DISCUSSION}

The results in the current investigation demonstrated that the progressive increase of rice bran in duck diets caused a significant linear reduction in ducks performance. This negative effect on performance parameters is well consistent with the results observed by Farrell, (1994). The depression of growth parameters under circumstances of the study may be ascribable to the ant-nutritive factors in rice bran. Phytate content, lectin, trypsin inhibitor and the breakdown of the lipid fraction that may occur during storage causes rancidity, are considered as a major disadvantage in rice bran that makes it limited to use in poultry diets (Farrell 1994). The salts of phytic acid (phytate) caused significant reduction in growth, feed intake and feed conversion ratio (Ravindran, 1995).

Another concept has been built on the basis of decreasing growth performance characteristics in response to increased dietary rice bran is that phytic acid may interact with proteins over a wide $\mathrm{PH}$ range forming phytateprotein complexes. Maenz (2001) explicated that phytin and protein can form binary complexes through electrostatic links of its charged phosphate groups with either the free amino group on arginine or lysine residues present within protein or with the terminal amino group on proteins. These binary phytin protein complexes may be formed at acidic $\mathrm{PH}$ de novo in the gut from the protein of cereal grains (Selle $\boldsymbol{e t}$ al., 2000).

Fayoum J. Agric. Res. \& Dev., Vol. 21, No. 2, July, 2007 
In the current investigation an adverse effect of increasing rice bran levels on the apparent digestibility coefficients of DM, CP, NFE, and CF was detected while the digestibility coefficients of $\mathrm{EE}$ and $\mathrm{ME}$ tended to be improved. The current results confirmed those reported by (Farrell, 1994 and Martin and Farrell., 1998). The decrease in CP digestibility coefficient with increasing rice bran levels in the current study could be attributed to phytic acid content in rice bran which may bind to or interact with dietary proteins, reducing their solubility or by altering the protein structure which leads to reduce the activity of endogenous proteases.

The decrease in $\mathrm{CF}$ digestibility coefficient of rice bran in the present investigation could be attributed to high fiber content rich in hemicelluloses containing branched arabinoxylans (Erbingerova et al., 1994). In the same direction, Narasinga Rao (1988) showed that rice bran contains $25.3 \mathrm{~g}$ of fiber per 100g; it includes cellulose, hemicelluloses (13\%) and pentosans $(6.5 \%)$ that are all insoluble fiber. It also contains about $(2 \%)$ soluble dietary fiber.

A desirable effect of increasing rice bran inclusion in ducks diets was noticed only with EE and AME digestibility coefficients. The increase of EE digestibility coefficient in response to increase rice bran in diets in the current study is compatible with the results observed by Martin and Farrell (1998). Increasing digestibility coefficient of EE may be attributed to the high quality fat content in rice bran. This statement is backed up by a study of Deis, (1997) who demonstrated that rice bran is rich source of fat $(16-22 \%)$. There is evidence that rice bran that contains $15 \%$ to $20 \%$ oil can serve as good source of energy and essential fatty acids (Narasinga Rao, 1988). Sugano and Tsuji, 1997 indicated that rice bran contains $20 \%$ of high quality fat with omega - 3, omega -6 , fatty acids, and other omega -3 fatty acids that manufactured in the body using alpha linolenic acid (ALA) such as eicosapentaenoic acid (EPA) and docosahexaenoic acid (DHA). The other omega - 6 fatty can be manufactured in the body using linoleic acid as a starting point; these include gamma - linoleic acid (GLA),dihomo-gama-linoleic acid (DHGLA) and arachidonic acid. They are essential for many biological processes, including oxygen use and energy production. In addition, the essential fatty acids are required to cell membranes construction and help in keeping red blood cells more flexible to find their way more easily through capillaries, consequently, the tissues and cells receive their supply of oxygen and nutrients more effectively and the metabolism therefore, increases. The increase in EE digestibility coefficient in the current study is suggestive to affect AME. This concept was highlighted by Martin and Farrell (1998) who stated that AME digestibility coefficient of rice bran was linearly related to oil metabolisability. It is interesting to note that the carbohydrate in bran is a complex mixture of carbohydrates and starch. Although starch is absent in true bran, commercial bran obtained from rice milling contains starch derived from the rice kernel, the content which may range from 10 to $25 \%$ depending on the extent of polishing (Narasinga Rao, 1988). Rice bran with low levels of available carbohydrate $25 \%$ and high level of fat $20 \%$ can be considered as a good source of energy and it is reflected to increase digestibility (Farrell, 1994).

In the current study, rice bran substantially increased the all investigated carcass parameters under study (giblets $\%$, GIT \%, abdominal fat $\%$, small intestine $\%$ and pancreas $\%$ ), this in turn led to decrease dressing percentage. Although the results of Mujahid et al., (2004) showed that liver and heart weights significantly increased with increasing rice bran in diet, it does not support such effect on dressing percentage. The increase in

Fayoum J. Agric. Res. \& Dev., Vol. 21, No. 2, July, 2007 
gastrointestinal tract size (GIT) reported in the current investigation could be attributed to fiber content in rice bran. This increase is almost like to that reported by Skland and Noy., (2003) who demonstrated that gastrointestinal tract and surface area increased by diets containing high level of crude fiber (soluble or insoluble). It is well known that some kinds of hemicelluloses are soluble fiber, It attracts water and turns to gel during digestion, thus, it leads to more water intake by birds (Zewil et al., 1990). This hydrophilic property of hemicelluloses can, to some extent, interpret why gastrointestinal tract increased in size with increasing rice bran inclusion in diets. Pancreas relative weigh increased also by increasing rice bran level in diets, this increment may be due to protease inhibitor in rice bran. According to Sayre, (1988), the feedstuffs containing protease inhibitors make the pancreas over work to produce more digestive enzymes, this process leads to enlargement the pancreas cells. This statement is backed up by a study of Martin and Farrell., (1998).

As shown in Table (5), rice bran lower plasma cholesterol levels. The same conclusion was observed Narasinga Rao, (1988). The hypocholesterolemic effects of rice bran may be attributed to the role of fiber content in rice bran in reducing cholesterol. Soluble fiber presented in rice bran forms a gel that binds with certain digestive acids made from cholesterol in liver and then takes the acids away in the feces. In response, liver draws cholesterol from blood to make more acids, thus lowering blood cholesterol. Soluble fiber also had the greatest effect on reducing total and low-density lipoprotein (LDL) as well as increase high-density lipoprotein (HDL). The hypercholesterolemic effect of full fat rice bran may be in part due to its phytochemicals content (dietary fiber, phytosterols, gamma oryzanol, tocopherol and tocotrienols, ferulic acid and other phenolic compounds). The other bioactive compounds present as minor constituents are lipoic acid, coenzyme $\mathrm{Q}$ etc.

Rice bran oil has been shown to reduce blood cholesterol as compared to other oils with comparable linoleic acid Raghuram., (1995). .Rice brain is rich in tocotrienols than tocopherols Kahlon et al., (1992) and Hegsted et al., (1990) . and it acts as antioxidants; tocotrienol is better than tocopherol in this respect. Tocotrienol has been shown to have a special role in reducing blood cholesterol and protect against heart disease by reducing de novo synthesis of cholesterol in the body by inhibiting the key enzyme HMG COA reductase and it acts also as anti-clotting Sugano and Tsuji., (1997). Gamma oryzanol is the main antioxidant in rice bran oil. This compound is presented in a small amount in other edible oils such as soybean and palm oil. Rice bran oil is considered as a rich source of this compound (nearly 19/100g). Oryzanol has been Rong et al., (1999) to decrease absorption of cholesterol and inhibit aortic fatty streak formation. The hypocholesterolemic potential of phytosterols has been demonstrated in man and experimental animals (Martin and farrell, 1988). Other minor compounds which are claimed to protect against heart disease are phenolic compound, ferulic acid, methyl ferulate, coenzyme $\mathrm{Q}_{10}$ and lipoic acid. The role of full fat rice bran in providing protection against heart disease is due to the contribution of all the phytochemicals described above and each of which has a tendency to reduce blood cholesterol by different mechanisms. It is not clear whether, if there is any synergistic effects of these compounds in reducing blood cholesterol. Sugano and Tsuji., (1997) showed that blending rice bran oil with sunflower oil magnified the hypocholesterolemic effect, but not when blend with corn oil. In this respect, the results of the current

Fayoum J. Agric. Res. \& Dev., Vol. 21, No. 2, July, 2007 
investigation may support the results obtained by Sugano and Tsuji (1997) where, the experimental diet used in the current study is contained sunflower oil. This result may confirm the collective synergistic effect between full fat rice bran and sunflower oil in reducing blood cholesterol.

In the current investigation, glucose concentration decreased as the level of rice bran increased. These results may be due to fiber content of rice bran where soluble fiber slows the passage of food into the intestine leading to greater control over the amount of glucose entering the blood stream. Soluble fiber slows absorption of blood sugar from the small intestine, making sugar level easier in control; it slows down the digestion of carbohydrates, which results in better glucose metabolism.

In view of undesirable effects of phytic acid, it is preferred to either remove it altogether or reduce its amount in poultry feed or ingredients. Efforts have been made in different laboratories to either eliminate or reduce phytic acid content in plant feedstuffs through chemical methods, solid sate fermentation technology, and autolysis or by the use of phytase enzyme in diet. Of these, microbial phytase supplementation appears to be more promising.

Feed intake and feed efficiency observed in the current investigation are similar to those reported by Namkung and Leeson (1999). This improvement may be explained by the fact that phytate -protein bonds were, to some extent, cleaved by phytase (Akyurek et al., 2005). Positive effects associated with microbial phytase supplementation in poultry diets include improved performance have been shown in the study of Ravindran et al., (2001) who elicited that the addition of phytase had significant linear effect on weight gain, feed: gain ratio, AME, protein and amino acid digestibility. Cowieson et al., (2004) concluded that phytate increases the excretion of endogenous minerals and amino acid in broiler chicken. Part of the beneficial effects by the addition of exogenous phytase to the diets of poultry appears to be mediated through a reduction in endogenous losses of amino acids, calcium, sodium, and phosphorus. Rutherfourd et al., (2002) showed that free lysine forms a complex with phytate. Approximately $20 \%$ of lysine was bound, but half of this was liberated after the addition of phytase. Ravindran et al. (2001) showed in their study that the addition of phytase to a lysine deficient diet significantly improved not only the ileal digestibility of lysine but also other amino acids therefore resulted in improved broiler performance. The microbial phytase addition increased the mean of amino acid digestibility by $3.4 \%$, which is higher than the increment (1.3 to $2.3 \%$ units) observed by Yi et al., (1996). Namkung and Lesson (1999) pointed out that phytase supplementation improved the ileal digestibility of all amino acids

The improvements in ducks performance in the current study may be also attributed to phytase supplementation while improved the absorptive function of the digestive tract. Wu et al. (2004) noticed some increases in villi height in the duodenum indicating that phytase had stimulating effect in improving absorptive capacity of the digestive canal.

The improvement in performance cannot be explained by improvements in protein and amino acid digestibility only but It has been observed that there were some effects on DM, CP, EE, NFE, and ME. This response is not surprising in that amino acid and starch digestibility were increased by phytase supplementation. The current results are compatible with the results observed by Morz et al. (1994) who reported that phytase increased total digestibility of DM

Fayoum J. Agric. Res. \& Dev., Vol. 21, No. 2, July, 2007 
and $\mathrm{CP}$. Based on the observation, that phytate is an integral component of the cell wall matrix in wheat (Frolich, 1990), it was postulated that microbial phytase may be acted in a manner similar to that of exogenous xylanases by disrupting cell walls and enhancing contact between digestive enzymes and cell contents, consequently, improved AME digestibility.

The data of the Ravindran et al., (2000) showed that phytase might improve energy utilization, independent of its effect on amino acid digestion through to the formation of insoluble metallic soaps in the gastrointestinal tract that is constraint lipid utilization. Phytase may reduce the degree of soap formation in the gut and enhance the utilization of energy derived from lipids. Akyurek et al., (2005) confirmed that addition of phytase improved the digestibility of crude fat. Starch digestibility is inversely related to phytate intake (Thompson, 1988). Phytate may influence starch digestibility through the interaction with proteins that are closely associated with starch (Thompson and Yoon, 1984), and calcium (Thompson, 1988) that catalyzes amylase activity, and with starch itself via phosphate links thereby lowering starch solubility and digestibility (Knuckles and Betschart 1987 and Li et al., 1993). Deshpande and Cheryan (1984) suggested that the capacity of phytate to inhibit amylase may play a physiological role in relation to starch reserves during seed germination.

The results of plasma concentration in the current study showed that glucose concentration was lowered due to increase rice bran in diet as a result of the inhibition effects of phytate. It has been demonstrated that manipulation of dietary phytate levels modifies the blood glucose response or glycemic index (Thompson et al., 1987). The glycemic index has shown to be negatively correlated with phytate concentrations in diets, which infers that phytate reduces carbohydrate digestibility (Yoon et al., 1983). Shelton et al. (2003) showed that the increase in glucose concentration by phytase may be explained by the positive effects of phytase on carbohydrate digestion and absorption (Williams et al., 2001).

The carcass traits data in the present study showed that phytase supplementation improved carcass traits except the giblets. These results are not coincided with the results observed by Qota et al., (2002), and Abdo (2004) who stated that microbial phytase did not alter dressing percentages, liver gizzard heart giblet and pancreas percentage.

\section{CONCLUSION}

It can be concluded that rice bran with microbial phytase could be used up to $60 \%$ in Muscovy ducks diets without any detrimental effect on performance and economic efficiency.

\section{REFERENCES}

Abdo, Z.M.A., 2004. Effect of phytase supplementation on the utilization of Nigella Sativa seed meal in broiler diets. Egypt.Poult. Sci. 24: 143162.

Akyurek, H., N. Senkoylu, and M.L. Ozduven, 2005. Effect of microbial phytase on growth performance and nutrients digestibility in broilers. Pakistan Journal of Nutrition. 4:22-26.

Annison, G., P.J. Moughan, and D.V. Thomas, 1995. Nutritive activity of soluble rice bran arabinoxy in broiler diets. Bri. poult. Sci. 36: 479488.

Fayoum J. Agric. Res. \& Dev., Vol. 21, No. 2, July, 2007 
A.O.A.C, 1995. Official Methods of Analysis (Sixteenth Edition).Association of Official Analytical Chemists, Washington, D.c.,USA.

Armstrong, W.D, and C.W. Carr, 1964. Physiological Chemistry Laboratory Directors. $3^{\text {rd }}$ Ed., Publishing Co., Minneapolis, Minnesta.

Blasco, A., J. Ouhayoun, and G., Masoero, 1992. Status of rabbit meat and carcass: Criteria and Terminology. Options Mediterranean's- Series Seminaries. No 17: $105-120$.

Bogin, E., and P. Keller, 1987. Application of clinical biochemistry to medically relevant animal models and standardization and quality control in animal biochemistry. J. Clin. Chem. Clin. Biochem. 25: 873 -878 .

Cowieson, A.J., T. Acamovic, and M.R., Bedford, 2004. The effect of phytase and phytic acid on endogenous losses from broiler chickens. Bri. Poult. Sci. 45:200-209.

Deis, R.C., 1997. Functional Ingredients from Rice Weeks Publishing Company.,USA.

Deshpande, S.S., and M., Cheryan, 1984. Effect of phytic acid, divalent cations, and their interactions on $\alpha$-amylase activity. J. Food Sci. 49: 516-524.

Der, G., and B.S. Everitt, 2001. A Handbook of Statistical Analysis using SAS. Second addition. CRC Press.

Duncan, D. B., 1955. Multiple ranges and multiple F tests. Biometrics. 11: 142.

Erbingerova, A., I. Hromadkova, and G.Berth, 1994. Structural and molecular properties of a water - soluble arabinoxylan - protein complex isolated from rice bran. Carbohydrate Research, 264:97-109.

Farrell, D.J., 1994. Utilization of rice bran in diets for domestic fowl and ducklings. World's Poult. Sci. J. 50: 115-131.

Frolich, W., 1990. Chelating properties of fiber and phytate. Pages 83-93 in New Developments in Dietary Fiber: Physioligical, Physiochemical and Analytical Aspects. I. Furda, and C. J. Brine, Ed. Premium Press, NY. USA.

Hegsted, M., M.M., Windhauser, and S.B., Laster, 1990. Stabilised rice bran and oat bran in humans. FASEBJ, 4, A368 (Abs .590).

Knuckles, B.E., and A.A., Betschart, 1987. Effect of phytate and other myoinositol phosphate esters on $\alpha$-amylase digestion. J. Food Sci. 52:719721.

Kahlon, T.S., F.I., Chow., R.N., Sayre, and A.A., Bestchart, 1992. Cholestrol lowering in Hamsters fed rice bran at different levels, rice bran and rice bran oil. J. Nutr. 122: 513-519.

Li,Z., I., Alli, and S., Kermasha, 1993. In vitro alpha - amylase inhibitor activity - phytate relationships in protein from phaseolus beans. Food Res . Int . 26: 195-201.

Lioyd, B.J., T.J. Siebenmorgen, and K.W. Beers, 2000. Effects of commercial processing on antioxidant in rice bran. Cereal Chem. 77: 551-555.

Maenz, D.D., 2001. Enzymatic characteristics of phytase as they relate to their use in animal feeds. In Enzymes in Farm Animal Nutrition. Partridge, G.G., CABI Publishing, 61-84.

Fayoum J. Agric. Res. \& Dev., Vol. 21, No. 2, July, 2007 
Martin, A., and D. I. Farrell, 1998. Strategies to improve the nutritive value of rice bran in poultry diets. II. Changes in oil digestibility metabolisable energy and attempts to increase the digestibility of the oil fraction in the diets of chickens and ducklings. Bri. Poult. Sci, 39: 555-559.

Morz,Z., A.W. Jongbloed, and P.A. Kemme, 1994. Apparent digestibility and retention of nutrients bound to phytate complexes as influenced by microbial phytase and feeding regimen in pigs. J. Anim. Sci. 72: 126132.

Mujahid, A. I.UI. Hag, M. Asif, and A.H., Gilani, 2004. Effect of different levels of rice bran processed by various techniques on performance of broiler chicks. Bri. Poult. Sci. 45:395-399.

Narasinga Rao, B.S., 1988. Dietary fiber in Indian diets and its nutritional significance. NFI Bulletin. 9:1-5.

Namkung, H., and S. Lesson, 1999. Effect of phytase enzyme on dietary nitrogen- corrected apparent metabolizable energy and ileal digestibility of nitrogen and amino acids in broiler chicks. Poult. Sci. 78: 1317-1319.

National Research Council (NRC), 1994. Nutrient Requirements of Poultry, $9^{\text {th }}$ ed. National Academy Press, Washington, D. C.,USA.

Onyango, E.M., M.R. Bedford, and O. Adeola, 2005. Efficacy of an evolved Escherichia coli phytase in diets of broiler chicks. Poult. Sci. 84: 248255.

Olukosi, O.A., A.J., Cowieson, and O. Adeola, 2007. Age-related influence of cocktail of xylanase, Amylase, and protease or phytase individually or in combination in broilers. Poult. Sci. 86: 77-86.

Qota, E., M.A., A.A. El-Ghamry, and G.M. El-Mallah, 2002. Nutritive value of soaked linseed cake as affected by phytase, biogen supplementation or formulating diets based on available amino acid on broiler performance. Egypt. Poult. Sci, 21:461-475.

Ravindran, A., 1995. Phytase in poultry nutrition-an overview proceedings of the Australian Poultry Symposium. 7:135-139.

Ravindran, V., S. Cabahus, G. Ravindran, P.H. Selle, and W.L., Bryden, 2000. Response of broiler chickens to microbial phytase supplementation as influenced by phytic acid and non phytate phosphorous level .П. Effect on apparent metabolisable energy, nutrient and nutrients retention .Bri. Poult. Sci. 41: 193-200.

Ravindran, V., P.H. Selle, G. Ravindran, P.C. Morel, H.A.K., Kies, and W.L., Bryden, 2001. Influence of supplemental microbial phytase on the performance, apparent metabolizable energy and ileal amino acid digestibility of broilers fed lysine deficient diet. Poul. Sci. 80: 338-344.

Raghuram, T.C., and C., Rukmini, 1999. Nutritional significance of rice bran oil.Ind.J.Med.Res.102:241-244.

Rong, N., L.M., Ausman, and R.J, Nicolosi., 1990. Oryzanol decreases cholesterol absorption and aortic fatty streaks in hamsters. lipids. 32: 303-309.

Rutherfourd, S.M., T.K.Chung, and P.J., Moughan, 2002. The effect of microbal phytase on ileal phosphorus and amino acid digestability in the broiler chicken. Bri. Poult. Sci. 44, 598-606.

Sayre, R.N., 1988. Rice bran as a source of adible oil and higher value chemicals. Cereal Foods World, 33: 684.

Fayoum J. Agric. Res. \& Dev., Vol. 21, No. 2, July, 2007 
Selle, P.H., V. Ravindran, R.R. Cladwell, and W.L., Bryden, 2000. Phytate and Phytase :consequences for protein utilization .Nutr. Res. Rev. 13: 255-278.

Shelton, J.L., L.L. Southern, T.D., Binder, M.A., Persica, J., Braun, B., Cousins, and F., Mcknight, 2003. Effect of microbial phytase on energy availability, lipid and protein deposition in growing swine .J . Anim. Sci. 81: 2053-2062.

Skland, D., and Y., Noy, 2003. Functional development and intestinal absorption in the young Poult. Brit. Poult. Sci. $8: 651-658$.

Sugano, M., and E. Tsuji, 1997. Nutrition: 10: 366-375.

Sutikno, A.I., 1990. Screening of aflatoxins in duck feedstuffs in west Java, Indonesia. J. Sci. Food and Agric. 50:459-465.

Tangendjaja, B, L.J. Cook, and J.R., Diment, 1986. Duck and chickens comparison on the utilization of rice bran during growing period Peternakan. 2: 137-139.

Thompson, L.U., 1988. Antinutrition and blood glucose. Food Technol. 42: 123-132.

Thompson, L.U., and H. Yoon, 1984. Starch digestibility as effected by polyphenols and phytic acid .J. Food Sci. 49:1228-1229.

Thompson, L.U., C.L. Button, and D.J.A. Jenkins ,1987. Phytic acid and calcium affect the in vitro of navy bean starch digestion and blood glucose response in humans. Am. J. Clin. Nutr . 46:467-473.

Wang, G.J., R.R. Marguardt, W. Guenterz, and Z., Zhong, 1997. Effect of enzyme supplementation and irradiation of rice bran on the performance of growing leghorn and broiler chickens. Anim . Feed Sci. Tech. 66:47-61

Williams, p., and R., losa, 2001. The use of essential oils and their compounds in poultry nutrition .World Poult. 17:14-15.

Wu, Y.B., V., Ravidran, D.G. Thomas, M.J. Birties, and W.H. Hendricks, 2004. Influence of phytase and xylanase, individually or in combination on performance, apparent metabolisable energy, digestive tract measurements and gut morphology in broilers fed wheat-based diets containing adequate level of phosphorus. Brit. Poult. Sci. 45: 76-84.

Yi, Z., E.T. Kornegay, and D.M. Denbow, 1996. Effect of microbial phytase on nitrogen and amino acid digestibility and retention of poults fed corn soybean meal diets. Poult. Sci. 75: 979-990.

Yoon , J.H., H.L.V. Thompson, and D.J A.Jenkins, 1983. The effect of phytic acid in vitro rate of starch digestibility and blood glucose response. Am. J. Clin. Nutr. 38: 835- 852.

Zeweil, H.S, G.K. Salwa, and N.S. Isshak, 2005. Effect of rice bran and enzyme mixture supplementation on performance, digestibility and carcass traits of growing Japanese quail. Egypt. Poult. Sci. 25:225-240.

Zeweil, H.S., N.S. Isshak and N. Badawy, 1990. Effects of pea by - product to replace yellow corn in the finisher ration on the performance of broiler ducklings. Egypt. Poult. Sci. 10: 69-82.

Fayoum J. Agric. Res. \& Dev., Vol. 21, No. 2, July, 2007 


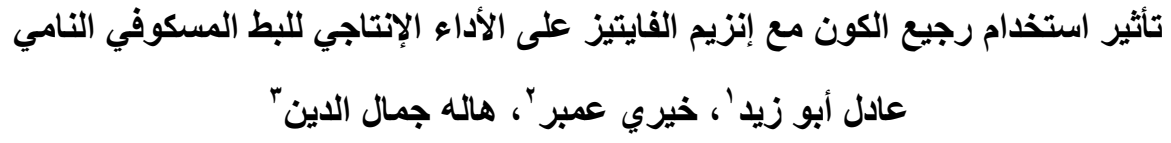

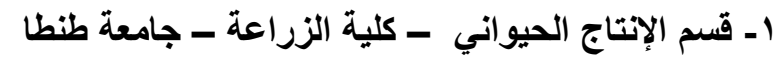

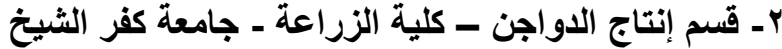

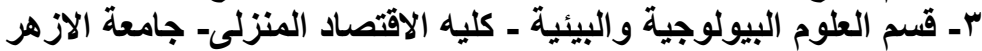

تهدف هذه الدراسة إلى تحديد تأثثر إضافة إنزيم الفايتيز إلى العلائق المحتوية على رجيع

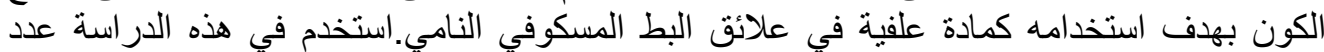

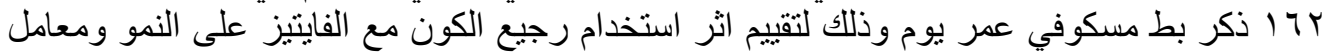

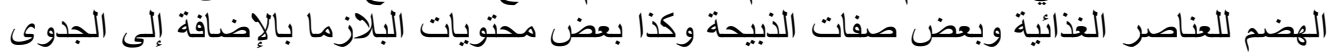

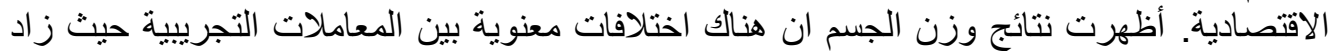

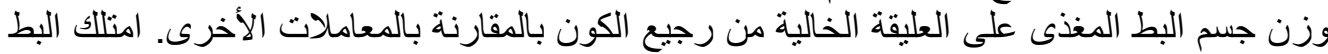

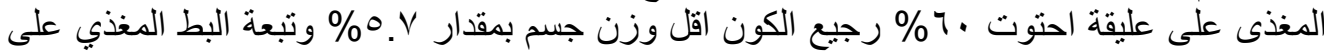

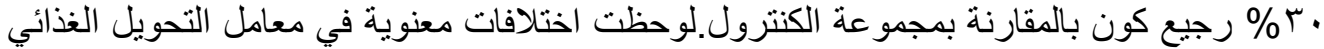

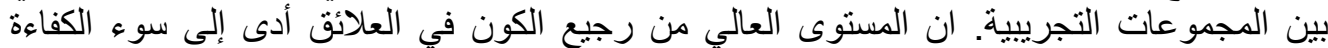

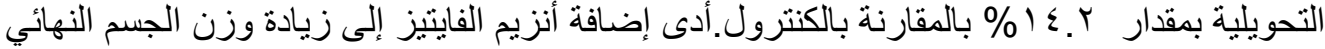

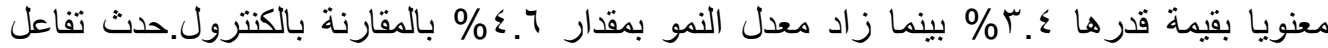

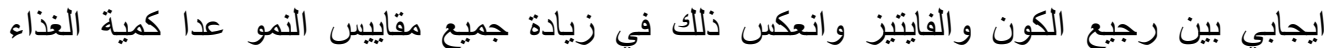

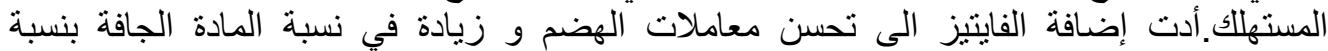

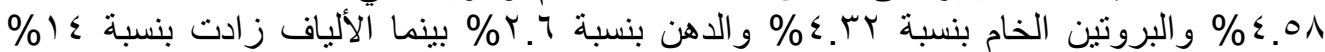

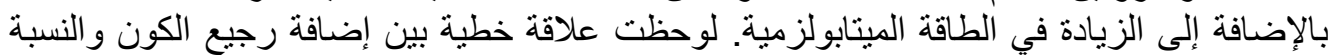

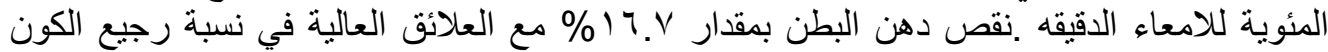

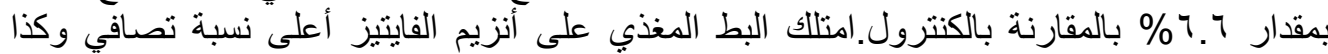

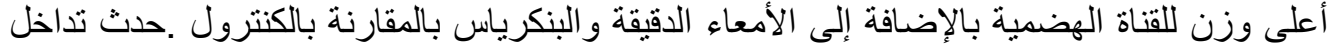

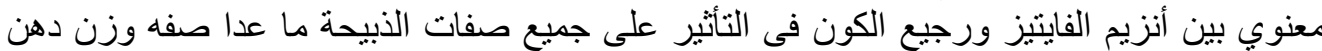

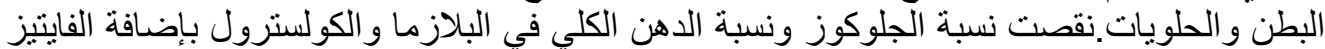

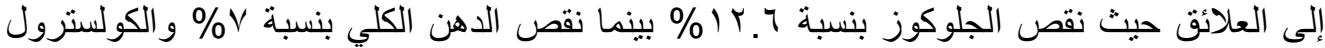

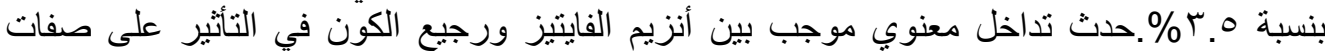

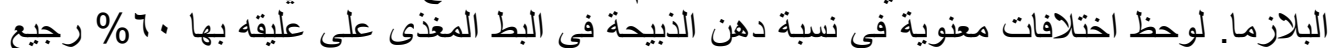

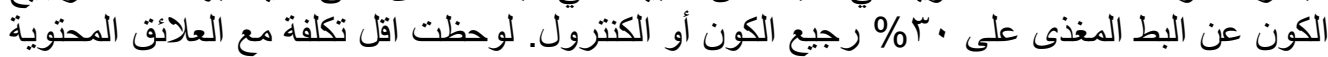

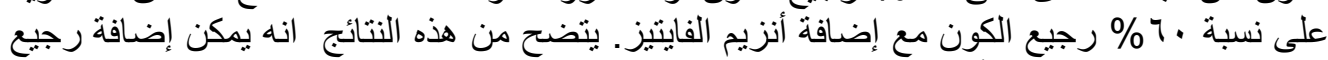
الكون حتى مستوى\% مع أنزيم الفايتيز في علائق البط النامي لتحقيق عائد اقتصادي جيد.

Fayoum J. Agric. Res. \& Dev., Vol. 21, No. 2, July, 2007 